history of no other wild animal is known in sea, air, or land. We are steadily compiling the lifehistory of other food-fishes. In 1902 the North Sea was an opaque grey mystery, in which the Admiralty had charted tidal streams and the Scottish Fishery Board had recorded unrelated surface-drift. In 1928 we know it a mosaic of moving blocks of water the individualities of which have been traced many hundreds of miles in their orderly processions. They are recorded, for the years of international observation, in progress up the Channel or round Scotland, along the 'broad Fourteens' or across by the Dogger, in movements as definite as those of spring Manitoban or American winter wheat, and with comparable economic significance. The vitamins that cure rickets and consumption have been followed from sunlit algæ, through protozoa, crustaceans, and small fish, to the cod which yields them to man. The unexpected history of phosphorus has been shown, with the vast unused hoards of the deep sea, stirred by beneficent storms until our herring are fed, twisted up by the Humboldt current so that the gulls of the South Pacific are able to make guano for English fields. In twenty other aspects of sea-life order now appears where a generation back we knew only curious detached facts and baffling anomalies. Best of all, perhaps, the research has yielded new discovery of curious detached facts and baffling anomalies, among which the labours of the next twenty-five years shall introduce new order, unlooked-for knowledge, and new material for the researches of generations to follow.

Of still wider interest is the achievement of these important results by team-work of united nations. In the continuance of this we are encouraged to look forward to further solution of scientific and economic problems which can be attacked successfully by no single nation. In the extension of such team-work may come regeneration of the world.

\title{
The Fixation of Shifting or Blown Sand.
}

$I^{\mathrm{N}}$ the Scottish Forestry Journal (vol. 42, pt. i.) Mr. J. F. Annand discusses the progress of the planting work on Culbin Sands, Morayshire. In the Annales de l'École Nationale des Eaux et Forêts (Nancy) et de la Station de recherches et expériences forestières (Tome 2, Fascic. 1, 1928) Monsieur H. Perrin, of the French Forest Service, deals with the same subject in a monograph entitled "La Fixation des Dunes maritimes en France." Since the world's classic example of this type of work was commenced in France a century and a half ago, a brief résumé of the French methods will be first given. The chief area dealt with by M. Perrin (he mentions others of a lesser importance) is the region on the western coast of France between the mouths of the Loire and the Adour, a stretch of fine white sand some 400 kilometres in length extending along the shores of the Bay of Biscay, forming an almost uninterrupted chain of dunes; the most important area lies to the south of the Gironde in Gascony between the latter river and the Adour, a distance of 231 kilometres, with a breadth of from 3 to 7 kilometres.

In 1804, Brémontier estimated the total area of the sand dunes in France at 155,000 hectares, of which 120,000 hectares were in Gascony. It was in this latter area, which owing to its importance and the damage the sand was causing in its march inland by covering up valuable agricultural lands, where the first studies were made some century and a half ago in this matter.

Some controversy has taken place on the subject of the power of shifting sand to continue its advance and destruction indefinitely. Brémontier more than a century ago held that the sand dunes continued an implacable advance in the direction of the prevailing winds, submerging everything in their passage at a rate of 20 metres per year. Others now hold that the sand is unable to advance beyond a certain distance from the coast; that when the wind from the sea lessens in force the sand is either blown back by the land winds or the dunes become stabilised and eventually covered with vegetation. Examples of old dunes of this kind are said to exist in Gascony. Nevertheless it is an established fact that a century and a half ago villages, vineyards, and forests were being gravely menaced in this region by the advance of the shifting sand; and further, the mouths of the rivers were blocked by bars resulting in their waters being held up, large areas of unhealthy marshes being formed just inside the coast line. In fact, at the period when the treatment of the sand was first undertaken the whole locality was malarious and the scanty population wracked with fevers.

The work to be briefly described has completely changed the countryside, which now contains a forest of great pecuniary value covering some 600,000 hectares and affording employment to a large healthy and wealthy population; though it should be remembered that the work in its inception was purely protective. The vegetation of the dunes before treatment and fixation consists in Gascony of the following: Psamma arenaria (the commonest species), Convolvulus soldanella, Eryngium maritimum, Ononis repens var. maritima, Cakile maritima, Euphorbia paralias, Galium maritimum, Linaria thymifolia, Silene Thorei, etc. Partial stabilisation brings in Carex arenaria, Helichrysum Stoechas and Aira canescens. When some soil has commenced to form on the sand the following make their appearance-Erica scoparia and cinerea, Salix repens, Cistus salvicefolius; Scirpus holoschoenus, Carex trinervis. On old-established dunes the forest appears, consisting of Pinus pinaster (the maritime pine) and several oaks (Quercus Ilex, Tozza, pedunculata, and in the south Q. Occidentalis and Suber (cork oak), with as undergrowth Polypodium vulgare, Pteris

No. 3080 , VoL. 122] 
aquilina, Osmunda Regalis, and, occasionally, Rubia peregrina.

This association of plants is of interest, because at the outset in the newly created forests of $P$. pinaster only a thin soil covering of mosses and lichens exists as undergrowth, some of the above species only appearing with the improvement of the soil. It is for this reason that two leguminous plants were introduced with the young pine crops, namely, the broom, Sarothamnus (Cytisus) scoparius and Ulex europoeus (gorse).

One hundred and fifty years ago this region in Gascony afforded a scanty pasturage to a few troops of half wild cattle and horses. A few scattered areas had been sown up with the seed of Pinus pinaster, but the problem of stabilising the sand had not been solved. In 1774 the Abbot Desbiey presented to the Academy of Sciences at Bordeaux a monograph dealing with the fixation of the dunes, but it was not published and was lost. In 1779, Colonel Baron de Charleroix-Villers, Inspector of Fortifications and Works, drew up a memoir, which is now a classic, on the fixation of the dunes and draining of the marshes. His views were approved by the Government, but effect was not given to them. The method of approaching this work was by that time understood, and had been already applied in Holland and Denmark. It was Brémontier, Chief Engineer of Roads and Bridges, who secured the Government's acceptance of his proposals, on the lines of CharleroixVillers, and started the work in 1787. Brémontier was associated with Peyjehan, a resin merchant who had already sown up some of the sand areas on his own account.

The work was successful from the outset, and it was continued until 1793 , by which time 94 hectares had been sown. The work was then interrupted owing to the disturbances due to the French Revolution. It was restarted in 1801 under a 'Commission of the Dunes,' the work being divided between the Roads and Bridges and the Forest Departments. It was carried on in this fashion until 1862, when the business was placed entirely under the Forest Department. By 1864, so far as the fixation of the dunes and the protection thereby gained, the work was completed ; 79,000 hectares (out of more than 100,000) had been stabilised and placed under forest at a total expenditure of $9,600,000$ francs $(122$ francs per

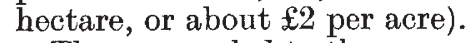

The success led to the recognition of the value of the recovered lands, and private proprietors took up the planting work and claimed some 21,000 hectares of the area which Government had thus brought under a valuable crop, claims which were admitted. What was commenced as a purely protective work has turned out a great financial success, the pine not only providing timber but also a resin which is more lucrative than the timber.

The work on the Culbin Sands in Morayshire will now be considered. These sands extend for about 4 miles along the coast of the Moray Firth. If Maviston Sand Hills, on the borders of the counties of Moray and Nairn, are included, the length of the coast line occupied is about 6 miles, and the breadth of the dunes varies from $1 \frac{1}{2}$ to 3 miles. Local tradition ascribes a sudden origin to the existing conditions, asserting that a large tract of once fertile land was overwhelmed and buried beneath the sand. Mr. Annand is probably correct in considering it as more probable that the process was a gradual one, going on more or less regularly or intermittently for centuries. It is, however, a historic fact that the final calamity took place in a great gale in January 1694, when the estate of Culbin, reputed so fertile as to be known as 'The Garden of Moray,' was invaded and overwhelmed in the great sand storm.

The Culbin area may be divided into three zones; (1) Towards the south or landward edge it is rather flat, with a sandy covering of moderate depth, intermingled with stretches of pebbly sand and small shallow marshes; (2) a middle zone consists of low sand dunes with partially fixed surface ; (3) farthest to the north and seawards a series of high dunes rises to a height in some instances of 120 feet or more, the dunes being unstabilised and destitute of vegetation. Stretches of flat shingly ground occur also throughout most of the higher dune zone.

The flora of the Culbin sands has been studied by Patton and Stewart (Trans. Bot. Soc. Edin., session Ixxix, 1914-15). As is the case in France, the moving sand is fixed by planting marram grass (Ammophila [Psamma] arenaria). When the sand is partially fixed various grasses and weed growth gradually establish themselves, all tending to bind the surface and, says Annand, "ultimately make it fit for tree-planting. Weed seeds have also been sown to hasten the process." Hair grass (Aira caryophyllea), Brome grass (Bromus sp.) and Yorkshire Fog have been tried with considerable success. Carex arenaria, Lotus corniculatus, Viola canina, are amongst species which establish themselves naturally at the earlier stages of fixation. Thereafter Calluna and Erica are plants which come in and help to complete the process.

During the last century a considerable part of the ground on the landward zone had been reclaimed from the sands and planted with trees. During the War the greater part of this timber was felled and removed. The task of replanting this area-the Forestry Commission acquired the area in 1922-has proved comparatively easy, the only difficulty having been the draining of the flat marshy parts where the sand dunes had interfered with the natural drainage, a similar state of affairs to that formerly existing in Gascony. More than 1000 acres of ground, mainly of this description, have already been planted.

As regards the work in connexion with the fixation of the moving sands, it is being carried out on somewhat similar lines to the French methods. Space unfortunately precludes a detailed description here of the latter methods, which are now well known or can be readily ascertained by consulting the two monographs here dealt with.

The vital difference between the two is, however, that the French sow the tree seed in situ, whereas

No. 3080, VoL. 122] 
at Culbin planting is resorted to. From the earliest French attempts as soon as the sand was sufficiently stablished, in othel words on the landward areas where the sand was not in active movement, they sowed a mixture of the seed of the maritime pine with the two leguminous plants, the broom and Ulex, the two latter having proved indispensable in assuring the successful development of the young pine. This method has been in force for 150 years, and its success in the case of the sands in Gascony is beyond dispute ; and it is cheap. The original species planted last century at Culbin was the Scots pine. Corsican pine appears now to offer prospects of heavier crops of timber, and is to be used extensively.

Whether the experiments so far carried out justify the change from the indigenous species is at least open to doubt; and the same applies to
Pinus contorta var. Murrayana, also supposed to be a rapid timber producer. But all these species are planted. Mr. Annand writes, "The process of fixation of the moving sand is somewhat slow, and three to four years must usually elapse before tree planting can be safely commenced. The work already done, however, appears to provide sufficient evidence that the afforestation of even the most mobile of the dunes can be successfully accomplished." As a matter of fact, this latter problem has not been in doubt for the last century or more. But it would not unlikely prove of easier solution if sowing on the well-tried French lines were resorted to. As regards costs, no comparison between the French and British expenditure is possible, as no data on this head are given for Culbin. Successful sowing is, however, infinitely cheaper than planting.

\section{Recent Excavations at the Cheddar Caves.}

\section{By R. F. Parry.}

$\mathrm{O}^{\mathrm{n}}$ WING to the increasing number of visitors to the famous caves at Cheddar, Somerset, it became advisable in the winter of 1927-28 to enlarge the entrance. When the cave was first discovered by the late R. C. Gough some thirty years ago, access to the inner portions was obtained by making a cutting through the debris which blocked the cave immediately inside the entrance. This cutting left standing banks of untouched cave earth on either side to a height of $4 \mathrm{ft} .6 \mathrm{in}$. against the cave walls. While this original work was in progress, many pieces of ancient pottery and flint tools were found, and when in 1903 a cutting was made for drainage purposes a little farther inside the cave, other finds were made, including the skeleton known as the 'Cheddar Man,' part of a bâton de commandement, and numerous flint implements $^{1}$

These earlier finds were made without any pretence to the keeping of any record that could be of use to scientific workers, and it was with the hope of throwing some light on these that the recent necessary work of excavation was carried out in a systematic manner : the excavations were carried down to a depth of $12 \mathrm{ft} .6 \mathrm{in}$, , or $8 \mathrm{ft}$. below the level of the path; at this depth rock bottom was reached. The soil was removed in 6-in. layers (numbered from the top downwards), and passed through a fine sieve. A careful record was kept of all finds, so that it is possible to refer any specimen to both its horizontal and vertical position in the deposits.

The cave is the course of an underground stream which in olden times flowed from the present cave mouth, but when the water found the lower level that it pursues to-day the cave became a shelter and was inhabited by man.

The stratification was as follows: The upper $2 \mathrm{ft} .6 \mathrm{in}$. was composed of the well-known red cave earth. so common in the Mendip caves; this was followed by $5 \mathrm{ft} .6 \mathrm{in}$. of a mixture of cave earth

1 Seligman and Parsons, Jour. Royal Anthro. Inst., vol. 44, p. 241.

No. 3080 , VoL. 122] and sand, the proportion of sand increasing with the depth. The layers here showed in section a laminated appearance, bands of clayey cave earth alternating with bands of almost pure sand. At $8 \mathrm{ft} .6 \mathrm{in}$. a bed of gravel $3 \mathrm{ft}$. thick was reached ; it was composed of waterworn limestone pebbles with a few of sandstone, with a filling of red cave earth and sand. This was no doubt the old river bed, and the upper layers also indicate periodical flooding by the river-an event by no means unknown in recent times. Below these layers came 6 in. of sand and clay, with very few pebbles, and at depths varying from $12 \mathrm{ft}$. to $12 \mathrm{ft}$. 6 in. the rock bottom of the cave was exposed.

Now going from above downwards the upper layers showed that the cave had been occupied during the Romano-British period followed by Early Iron Age man, who left behind, amongst other things, a fine bone lance head or point very similar to one from Park Brow, Cissbury, ${ }^{2}$ and to some from the Glastonbury and Meare lake villages, pottery of distinctive types, and a bronze two-whorl ring. Immediately below these came implements of definitely Palæolithic types. Layers 9 and 10 were somewhat mixed, giving artefacts of both Early Iron Age and Palæolithic date, and showing also a mixture of recent and Pleistocene animal remains. There were no signs of occupation during the Bronze or Neolithic periods, and yet there were no blank layers, and the deposits go without a break from the Early Iron Age into the Palæolithic Age: a decidedly remarkable occurrence.

The first finds of Palæolithic date commenced in layer 7, and continued downwards to the last layer. A large number of flint implements, including knives, scrapers, borers, and burins, were found. In all, 1749 flints were taken from the excavation, 244 of which were definitely worked implements-a proportion of about 14 per cent. The long narrow flake used as a knife of the

\footnotetext{
2 R. A. Smith, Archoologia, vol. 76.
} 